\title{
Anti-SARS-CoV-2 antibodies in the CSF, blood-brain barrier dysfunction, and neurological outcome
}

\author{
Studies in 8 stuporous and comatose patients
}

Harry Alexopoulos, PhD, Eleni Magira, MD, Kleopatra Bitzogli, MSc, Nikolitsa Kafasi, MD, Panayiotis Vlachoyiannopoulos, MD, Athanasios Tzioufas, MD, Anastasia Kotanidou, MD, and Marinos C. Dalakas, MD, FAAN

Neurol Neuroimmunol Neuroinflamm 2020;7:e893. doi:10.1212/NXI.0000000000000893

\section{Abstract}

\section{Objective}

To investigate the pathophysiologic mechanism of encephalopathy and prolonged comatose or stuporous state in severally ill patients with coronavirus disease 2019 (COVID-19).

\section{Methods}

Eight COVID-19 patients with signs of encephalopathy were tested for antibodies to severe acute respiratory syndrome coronavirus 2 (SARS-CoV-2) in the serum and CSF using a Food and Drug Administration-approved and independently validated ELISA. Blood-brain barrier (BBB) integrity and immunoglobulin $\mathrm{G}(\mathrm{IgG})$ intrathecal synthesis were further tested using albumin and IgG indices. The CSF was also tested for autoimmune encephalitis antibodies and 14-3-3, a marker of ongoing neurodegeneration.

\section{Results}

All patients had anti-SARS-CoV-2 antibodies in their CSF, and 4 of 8 patients had high titers, comparable to high serum values. One patient had anti-SARS-CoV-2 IgG intrathecal synthesis, and 3 others had disruption of the blood-brain barrier. The CSF in 4 patients was positive for 14-3-3-protein suggesting ongoing neurodegeneration. In all patients, the CSF was negative for autoimmune encephalitis antibodies and SARS-CoV-2 by PCR. None of the patients, apart from persistent encephalopathic signs, had any focal neurologic signs or history or specific neurologic disease.

\section{Conclusions}

High-titer anti-SARS-CoV-2 antibodies were detected in the CSF of comatose or encephalopathic patients demonstrating intrathecal IgG synthesis or BBB disruption. A disrupted $\mathrm{BBB}$ may facilitate the entry of cytokines and inflammatory mediators into the CNS enhancing neuroinflammation and neurodegeneration. The observations highlight the need for prospective CSF studies to determine the pathogenic role of anti-SARS-CoV-2 antibodies and identify early therapeutic interventions.
Correspondence

Dr. Dalakas

mdalakas@med.uoa.gr

\section{COVID-19 Resources}

For the latest articles, invited commentaries, and blogs from physicians around the world NPub.org/COVID19

From the Neuroimmunology Unit (H.A., K.B., M.C.D.), Department of Pathophysiology (P.V., A.T.), and 1st Department of Intensive Care Medicine (E.M., A.K.), Evangelismos Hospital, Faculty of Medicine, National and Kapodistrian University of Athens; and Department of Immunology and Histocompatibility (N.K.), Laikon University Hospital, Athens, Greece. 


\section{Glossary}

BBB = blood-brain barrier; COVID-19 = coronavirus disease 2019; ICU = intensive care unit; IgG = immunoglobulin G; SARS-CoV-2 = severe acute respiratory syndrome coronavirus 2 .

Coronavirus disease 2019 (COVID-19) may present with or cause severe neurologic disorders with the most commonly reported strokes, Guillain-Barré syndrome, and encephalopathies. In particular, several intensive care unit (ICU)-treated patients-despite respiratory improvement or sedation withdrawal-display encephalopathic signs and difficulty or inability to regain consciousness. ${ }^{1,2}$ Whether this is related to viral neuroinvasion, ${ }^{3}$ systemic metabolic effects, ${ }^{4}$ or disruption of the blood-brain barrier (BBB) and leakage into the brain of peripherally circulating inflammatory mediators is still unclear. To address this issue, we conducted a clinical and laboratory study in critically ill, ICU-hospitalized, COVID-19 patients exhibiting signs of encephalopathy focusing on CSF analysis, BBB dysfunction, and COVID-19 CSF antibody production.

\section{Methods}

A total of 47 patients, positive for severe acute respiratory syndrome coronavirus 2 (SARS-CoV-2) by PCR, were hospitalized in the ICU of a University Hospital in Athens, Greece, between April 15 and June 15. Eight of these patients (4 men and 4 women, age range 57-84) are presented in this study because they had signs of encephalopathy, including altered mental status, confusion, delirium, stupor, or coma, either before intubation or after sedation withdrawal when their respiratory status had improved.

Matching serum and CSF samples, synchronous to the neurologic assessments, were tested for anti-SARS-CoV-2 immunoglobulin $\mathrm{G}(\mathrm{IgG})$ antibodies using a recently Food and Drug Administration-approved and independently validated ELISA method (Euroimmun, Lübeck, Germany) according to the manufacturer's instructions. ${ }^{5}$ Furthermore, the albumin and IgG indices were calculated to determine BBB permeability and total IgG intrathecal synthesis. The CSF was also tested for (1) SARS-CoV-2 genetic determination with PCR; (2) autoimmune encephalitis autoantibodies, including antiNMDAr, AMPAr, GABAbr, CASPR2, DPPX, and LGI1, using a cell-based assay (Euroimmun); and (3) for 14-3-3 protein, a marker of neurodegeneration, using Western Blot and an anti-14-3-3 polyclonal antibody (Millipore, Darmstadt, Germany). The results were correlated with the patients' neurologic status and subsequent outcome.

\section{Standard protocol approvals, registrations, and patient consents}

The study protocol was reviewed and approved by the institutional review boards of each center per local regulations. All patients or legally accepted representatives of the patients provided written informed consent before study entry for the present analysis. The study was conducted in compliance with the ethical principles of the Declaration of Helsinki.

\section{Data availability}

Anonymized data will be made available to qualified external researchers, with requests reviewed and approved by an independent review panel on the basis of scientific merit.

\section{Results}

None of the 8 patients had any neurologic history or focal neurologic signs including any apparent conditions that could lead to BBB disruption. All patients had increased C-reactive protein $(>0.5 \mathrm{mg} / \mathrm{dL})$ on admission. Their basic laboratory and clinical parameters, including comorbidities and COVID-19related symptoms, are presented in the table e-1 (links.lww. com/NXI/A317). The average disease duration was 45.6 days, and the average SOFA score was 8.87 (range 7-11). All patients had typical pulmonary imaging of diffuse infiltrates and ground glass opacities requiring intubation. Four of 8 patients $(50 \%)$ eventually developed renal failure, and 1 of 8 patients (12.5\%) had hepatic failure. Patient 1 (table 1) presented with agitated confusion; none of the others had any neurologic symptoms at hospital admission. After prolonged ICU stay (36.7 days on average) and despite pulmonary improvement or successful extubation, 3 patients remained comatose and 3 stuporous, whereas 2 others still required sedation. Three patients eventually died. No specific neurologic signs, especially focal vascular events, were observed either before intubation or after sedation withdrawal.

All patients had high titer of anti-SARS-CoV-2 IgG antibodies in their serum (table 1). Their CSF also contained anti-SARS-CoV$2 \mathrm{IgG}$ antibodies in all the patients at 1:10 dilution, but in none of 20 control CSF samples from other CNS diseases. In 4 of 8 patients, the CSF antibody titers were very high, comparable to the serum titers, detectable at 1:100 dilution. In all study patients, the CSF were PCR-negative for SARS-CoV-2.

In 1 patient (3, table 1$)$, the serum and CSF antibodies were initially negative, but both became positive within 12 days as the patient clinically deteriorated. Another patient (6, table 1) was initially only seropositive, but 1 week later, after clinical worsening, a repeated CSF sample had become SARS-CoV-2 antibody positive. Albumin and IgG indices showed that 1 patient (1, table 1$)$ had IgG index of 1.85 (normal <0.77) denoting intrathecal synthesis, whereas 3 others $(2,3,8)$ had albumin index $>20 \times 10^{-3}$ (normal $<10 \times 10^{-3}$ ) denoting BBB disruption. The CSF in 4 patients was positive for 14-3-3-protein suggesting the onset of neurodegeneration. All patients were negative for autoimmune 
Table 1 Anti-SARS-CoV-2 antibodies in serum and CSF, intrathecal synthesis, blood brain barrier disturbance and neurologic status of patients

\begin{tabular}{|c|c|c|c|c|c|c|c|c|c|}
\hline $\begin{array}{l}\text { Patient } \\
\text { samples }\end{array}$ & $\begin{array}{l}\text { Serum IgG }(1: 100 \\
\text { dilution })>1.1^{a}\end{array}$ & $\begin{array}{l}\text { CSF 1: } \\
100>1.1\end{array}$ & $\begin{array}{l}\text { CSF 1: } \\
10>1.1\end{array}$ & $\begin{array}{l}\text { IgG index } \\
\text { normal }<0.77\end{array}$ & $\begin{array}{l}\text { Albumin } \\
\text { index }>20 \times \\
10^{-3}\end{array}$ & $\begin{array}{l}14- \\
3-3\end{array}$ & $\begin{array}{l}\text { Autoimmune } \\
\text { encephalitis }\end{array}$ & $\begin{array}{l}\text { Main CNS } \\
\text { clinical } \\
\text { findings }\end{array}$ & Outcome \\
\hline 1 & 9.81 & 2.87 & 8.64 & 1.85 & $4 \times 10^{-3}$ & POS & NEG & Coma: GCS 4 & Death \\
\hline 2 & 9.45 & 1.50 & 5.35 & 0.36 & $24 \times 10^{-3}$ & POS & NEG & Coma: GCS 9 & $\mathrm{ICU}$ \\
\hline 3 & NEG & NEG & NEG & 0.41 & $5 \times 10^{-3}$ & NEG & NEG & Under sedation & ICU \\
\hline $\begin{array}{l}3^{\prime}(12 \\
\text { d later) }\end{array}$ & 8.62 & 1.53 & 6.42 & 0.39 & $25 \times 10^{-3}$ & POS & NEG & - & - \\
\hline 4 & 9.68 & NEG & 2.39 & 0.46 & $3 \times 10^{-3}$ & NEG & NEG & $\begin{array}{l}\text { Somnolence: } \\
\text { GCS } 15\end{array}$ & $\mathrm{ICU}$ \\
\hline 5 & 8.33 & NEG & 2.10 & 0.29 & $4 \times 10^{-3}$ & NEG & NEG & $\begin{array}{l}\text { Somnolence: } \\
\text { GCS } 6\end{array}$ & Death \\
\hline 6 & 7.95 & NEG & NEG & 0.27 & $4 \times 10^{-3}$ & NEG & NEG & Under sedation & ICU \\
\hline $\begin{array}{l}6^{\prime}(7 \\
\text { d later) }\end{array}$ & 8.62 & NEG & 1.83 & 0.27 & $4 \times 10^{-3}$ & NEG & NEG & - & - \\
\hline 7 & 7.17 & NEG & 1.56 & 0.44 & $3 \times 10^{-3}$ & POS & NEG & $\begin{array}{l}\text { Somnolence: } \\
\text { GCS } 13\end{array}$ & ICU \\
\hline 8 & 7.80 & 2.23 & 5.13 & 0.37 & $25 \times 10^{-3}$ & NEG & NEG & Coma: GCS 7 & Death \\
\hline
\end{tabular}

Abbreviations: GCS = Glasgow Coma Scale; ICU = intensive care unit; IgG = immunoglobulin G; NEG = negative; POS = positive; SARS-CoV-2 = severe acute respiratory syndrome coronavirus 2 .

Numbers in bold indicate above the normal range.

a Index is calculated by dividing absorbance of samples @450 nm (1:100 or 1:10 dilution) to absorbance of calibrator @450 nm according to the manufacturer's instructions. The cutoff for antibody positivity is $>1.1$.

encephalitis antibodies. Routine CSF analysis was normal, excluding any known infectious processes.

\section{Discussion}

We report the detection of anti-SARS-CoV-2 antibodies in the CSF, performed with a validated ELISA assay, in conjunction with BBB permeability analysis. The study demonstrates that the CSF in all encephalopathy patients was positive for anti-SARS-CoV-2 antibodies, but $50 \%$ of them have high CSF antibody titers and disrupted BBB or increased intrathecal IgG synthesis. The patients' CSF was otherwise normal and SARS-CoV-2 negative by PCR, consistent with most published studies, ${ }^{6,7}$ excluding the possibility of direct SARS-CoV-2 neuroinvasion. The cause and consequence of disturbed BBB needs to be elucidated. The widely reported high levels of circulating proinflammatory cytokines due to SARS-CoV-2 infection possibly disrupt the BBB allowing for antibodies and other inflammatory mediators to enter the brain parenchyma, as recently shown. ${ }^{8}$ Systemic effects related to multiorgan failure may be additional factors facilitating BBB disturbance. Endothelial cells, which are a structural part of the BBB, can also be directly affected by the virus or the circulating cytokines resulting in endotheliaitis, which further compromises the BBB integrity. The antiSARS-CoV-2 antibodies entering or produced in the CNS compartment can directly induce or perpetuate neurologic damage by mobilizing complement or guiding SARS-CoV2-infected macrophages. ${ }^{9}$

Apart from the inferred role of neuroinflammation, there is also evidence of ongoing neurodegeneration in some of our encephalopathic patients, as supported by the noted 14-3-3 CSF positivity in patients with poor outcome. This is also consistent with a recent finding of elevated neuronal injury markers in the sera of COVID-19 patients, ${ }^{10}$ suggesting that search for such markers in the CSF is warranted. In more than $60 \%$ of patients with prolonged encephalopathy and stupor, brain MRI has been uninformative; however, in other series vascular or necrotic lesions have been observed suggesting that in addition to elevated markers of systemic inflammation, virus-induced hypercoagulable states, multiorgan system dysfunction, or hypoxemia may also play a role. ${ }^{1,11}$

Despite the lack of imaging studies, the study's main limitation due to apparent difficulties in obtaining brain MRI's in severely ill COVID-19 ICU patients, the demonstration of disturbed BBB with high-titers anti-SARS-CoV-2 antibodies in the CSF is important in understanding the mechanism of encephalopathies in these patients. These observations highlight the need for future prospective CSF studies from severely ill COVID-19 patients to determine the role of CSF antibodies in triggering neuroinflammation, exploring markers of neurodegeneration, and initiating proper therapeutic interventions. 
Study funding

No targeted funding reported.

\section{Disclosure}

The authors report no relevant disclosures.Go to Neurology. org/NN for full disclosures.

\section{Publication history}

Received by Neurology: Neuroimmunology \& Neuroinflammation July 22, 2020. Accepted in final form August 25, 2020.

\section{Appendix Authors}

\begin{tabular}{|c|c|c|}
\hline Author & Location & Contribution \\
\hline $\begin{array}{l}\text { Harry Alexopoulos, } \\
\text { PhD }\end{array}$ & $\begin{array}{l}\text { Neuroimmunology } \\
\text { Unit, Department of } \\
\text { Pathophysiology, } \\
\text { Faculty of Medicine, } \\
\text { National and } \\
\text { Kapodistrian University } \\
\text { of Athens, Greece }\end{array}$ & $\begin{array}{l}\text { Designed and } \\
\text { conceptualized the } \\
\text { study, acquired and } \\
\text { interpreted data, and } \\
\text { drafted the } \\
\text { manuscript for } \\
\text { intellectual content }\end{array}$ \\
\hline Eleni Magira, MD & $\begin{array}{l}\text { 1st Department of } \\
\text { Intensive Care } \\
\text { Medicine, } \\
\text { Evangelismos Hospital, } \\
\text { Faculty of Medicine, } \\
\text { National and } \\
\text { Kapodistrian University } \\
\text { of Athens, Greece }\end{array}$ & $\begin{array}{l}\text { Acquired and } \\
\text { interpreted data and } \\
\text { drafted the } \\
\text { manuscript for } \\
\text { intellectual content }\end{array}$ \\
\hline $\begin{array}{l}\text { Kleopatra Bitzogli, } \\
\text { MSc }\end{array}$ & $\begin{array}{l}\text { Neuroimmunology } \\
\text { Unit, Department of } \\
\text { Pathophysiology, } \\
\text { Faculty of Medicine, } \\
\text { National and } \\
\text { Kapodistrian } \\
\text { University of Athens, } \\
\text { Greece }\end{array}$ & $\begin{array}{l}\text { Acquired and } \\
\text { interpreted data }\end{array}$ \\
\hline Nikolitsa Kafasi, MD & $\begin{array}{l}\text { Department of } \\
\text { Immunology and } \\
\text { Histocompatibility, } \\
\text { Laikon University } \\
\text { Hospital, Athens, } \\
\text { Greece }\end{array}$ & $\begin{array}{l}\text { Acquired and } \\
\text { interpreted data }\end{array}$ \\
\hline $\begin{array}{l}\text { Panayiotis } \\
\text { Vlachoyiannopoulos, } \\
\text { MD }\end{array}$ & $\begin{array}{l}\text { Department of } \\
\text { Pathophysiology, } \\
\text { Faculty of Medicine, } \\
\text { National and } \\
\text { Kapodistrian } \\
\text { University of Athens, } \\
\text { Greece }\end{array}$ & $\begin{array}{l}\text { Drafted the } \\
\text { manuscript for } \\
\text { intellectual content }\end{array}$ \\
\hline
\end{tabular}

Appendix (continued)

\begin{tabular}{|c|c|c|}
\hline Author & Location & Contribution \\
\hline $\begin{array}{l}\text { Athanasios Tzioufas, } \\
\text { MD }\end{array}$ & $\begin{array}{l}\text { Department of } \\
\text { Pathophysiology, } \\
\text { Faculty of Medicine, } \\
\text { National and } \\
\text { Kapodistrian University } \\
\text { of Athens, Greece }\end{array}$ & $\begin{array}{l}\text { Drafted the } \\
\text { manuscript for } \\
\text { intellectual content }\end{array}$ \\
\hline $\begin{array}{l}\text { Anastasia Kotanidou, } \\
\text { MD }\end{array}$ & $\begin{array}{l}\text { 1st Department of } \\
\text { Intensive Care } \\
\text { Medicine, } \\
\text { Evangelismos Hospital, } \\
\text { Faculty of Medicine, } \\
\text { National and } \\
\text { Kapodistrian University } \\
\text { of Athens, Greece }\end{array}$ & $\begin{array}{l}\text { Acquired and } \\
\text { interpreted data and } \\
\text { drafted the } \\
\text { manuscript for } \\
\text { intellectual content }\end{array}$ \\
\hline $\begin{array}{l}\text { Marinos C. Dalakas, } \\
\text { MD, FAAN }\end{array}$ & $\begin{array}{l}\text { Neuroimmunology } \\
\text { Unit, Department of } \\
\text { Pathophysiology, } \\
\text { Faculty of Medicine, } \\
\text { National and } \\
\text { Kapodistrian University } \\
\text { of Athens, Greece, and } \\
\text { Department of } \\
\text { Neurology, Thomas } \\
\text { Jefferson University, } \\
\text { Philadelphia, PA, USA }\end{array}$ & $\begin{array}{l}\text { Designed and } \\
\text { conceptualized the } \\
\text { study, acquired and } \\
\text { interpreted data, } \\
\text { drafted the } \\
\text { manuscript for } \\
\text { intellectual content, } \\
\text { and senior author }\end{array}$ \\
\hline
\end{tabular}

\section{References}

1. Koralnik IJ, Tyler KL. COVID-19: a global threat to the nervous system. Ann Neurol $2020 ; 88: 1-11$

2. Moriguchi T, Harii N, Goto J, et al. A first case of meningitis/encephalitis associated with SARS-Coronavirus-2. Int J Infect Dis 2020;94:55-58

3. Puelles VG, Lutgehetmann M, Lindenmeyer MT, et al. Multiorgan and renal tropism of SARS-CoV-2. N Engl J Med 2020;383:590-592.

4. Benussi A, Pilotto A, Premi E, et al. Clinical characteristics and outcomes of inpatients with neurologic disease and COVID-19 in Brescia, Lombardy, Italy. Neurology 2020, 95:e910-e920.

5. Stringhini S, Wisniak A, Piumatti G, et al. Seroprevalence of anti-SARS-CoV-2 IgG antibodies in Geneva, Switzerland (SEROCoV-POP): a population-based study. Lancet 2020;396:313-319.

6. Dalakas MC. Guillain-Barré syndrome: the first documented COVID-19-triggered autoimmune neurologic disease: more to come with myositis in the offing. Neurol Neuroimmunol Neuroinflamm 2020;7:e781.

7. Al Saiegh F, Ghosh R, Leibold A, et al. Status of SARS-CoV-2 in cerebrospinal fluid of patients with COVID-19 and stroke. J Neurol Neurosurg Psychiatry 2020;91:846-848.

8. Bodro M, Compta Y, Llansó L, et al. Increased CSF levels of IL-1 $\beta$, IL-6, and ACE in SARSCoV-2-associated encephalitis. Neurol Neuroimmunol Neuroinflamm 2020;7:e821.

9. Park MD. Macrophages: a Trojan horse in COVID-19? Nat Rev Immunol 2020;20:351.

10. Kanberg N, Ashton NJ, Andersson LM, et al. Neurochemical evidence of astrocytic and neuronal injury commonly found in COVID-19. Neurology Epub 2020 Jun 16.

11. Zubair AS, McAlpine LS, Gardin T, Farhadian S, Kuruvilla DE, Spudich S. Neuropathogenesis and neurologic manifestations of the coronaviruses in the age of coronavirus disease 2019: a review. JAMA Neurol Epub 2020 May 29. 


\title{
Neurology \\ Neuroimmunology \& Neuroinflammation
}

\author{
Anti-SARS-CoV-2 antibodies in the CSF, blood-brain barrier dysfunction, and \\ neurological outcome: Studies in 8 stuporous and comatose patients \\ Harry Alexopoulos, Eleni Magira, Kleopatra Bitzogli, et al. \\ Neurol Neuroimmunol Neuroinflamm 2020;7; \\ DOI 10.1212/NXI.0000000000000893
}

This information is current as of September 25, 2020

\section{Updated Information \& \\ Services}

References

Citations

Subspecialty Collections

Permissions \& Licensing

Reprints including high resolution figures, can be found at:

http://nn.neurology.org/content/7/6/e893.full.html

This article cites 9 articles, 3 of which you can access for free at: http://nn.neurology.org/content/7/6/e893.full.html\#\#ref-list-1

This article has been cited by 3 HighWire-hosted articles: http://nn.neurology.org/content/7/6/e893.full.html\#\#otherarticles

This article, along with others on similar topics, appears in the following collection(s):

COVID-19

http://nn.neurology.org//cgi/collection/covid_19

Encephalitis

http://nn.neurology.org//cgi/collection/encephalitis

Information about reproducing this article in parts (figures,tables) or in its entirety can be found online at:

http://nn.neurology.org/misc/about.xhtml\#permissions

Information about ordering reprints can be found online:

http://nn.neurology.org/misc/addir.xhtml\#reprintsus

Neurol Neuroimmunol Neuroinflamm is an official journal of the American Academy of Neurology.

Published since April 2014, it is an open-access, online-only, continuous publication journal. Copyright

Copyright (C) 2020 The Author(s). Published by Wolters Kluwer Health, Inc. on behalf of the American

Academy of Neurology.. All rights reserved. Online ISSN: 2332-7812.

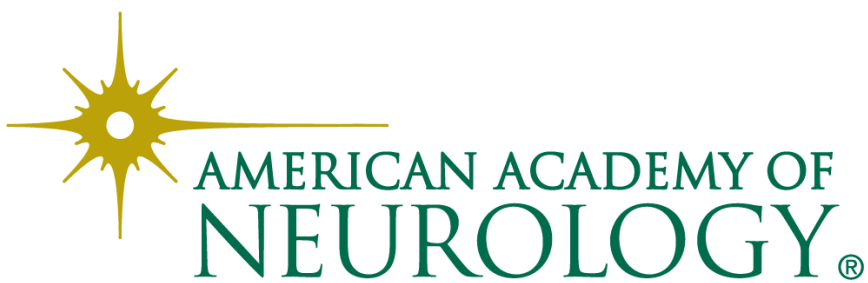

